\title{
A Dialogic Model for Telecollaboration
}

\author{
Francesca Helm \\ University of Padua, \\ Padua, Italy
}

(Article received 29 January 2013; final version received 28 April 2013)

\begin{abstract}
In language learning contexts, telecollaboration is understood to be internetbased intercultural exchange between people of different cultural/national backgrounds set up in an institutional context with the aim of developing both language skills and intercultural communicative competence. Generally students interact with one another on 'safe' topics and subsequently reflect on and discuss their interactions with teachers and peers. This paper presents a dialogic model of telecollaboration which breaks from this tradition as it entails interaction on topics which are seen as divisive through dialogue in groups led by trained facilitators, the Soliya Connect Program (SCP). The differences between this model of telecollaboration and traditional models are illustrated, and then the author presents the results of a survey study which looks at participants' evaluation of this program, what they perceive to be the role of the facilitators and their personal learning outcomes.
\end{abstract}

\section{Introduction}

Telecollaboration in foreign language education is online intercultural exchange between classes of students in geographically distant locations (Dooly, 2008). In the twenty or so years that telecollaboration has evolved as a pedagogic approach several models have emerged, with diverse learning objectives, involving different typologies and configurations of participants, and utilizing a range of languages and modalities of language use. What most of these established models of telecollaboration share is that interaction generally occurs directly between participants who engage in tasks designed to foster language skills and intercultural communicative competence. It is also important, however, that foreign language education be concerned not only with instrumental aims but also humanistic ones, and promote not only the acquisition of language and intercultural skills and competences but also intercultural dialogue and understanding.

Intercultural dialogue has recently become a key area of European policy. In 2008, recognizing the inadequacy of 'assimilationist' and 'multicultural' models of dealing with the increasing diversity of society, the Council of Europe published the White Paper on Intercultural Dialogue. In this document, intercultural dialogue is defined as follows:

a process that comprises an open and respectful exchange of views between individuals and groups with different ethnic, cultural, religious and linguistic backgrounds and heritage, on 
the basis of mutual understanding and respect. It requires the freedom and ability to express oneself, as well as the willingness and capacity to listen to the views of others. Intercultural dialogue contributes to political, social, cultural and economic integration and the cohesion of culturally diverse societies. It fosters equality, human dignity and a sense of common purpose. It aims to develop a deeper understanding of diverse world views and practices, to increase co-operation and participation (or the freedom to make choices), to allow personal growth and transformation, and to promote tolerance and respect for the other. (2008, p.17)

Promoting intercultural dialogue as well as communicative competence is thus an imperative for educators, and foreign language education is one of the areas in which intercultural dialogue can find a collocation.

The paper begins with a brief review of established models of telecollaboration, with a focus on the objectives of these models, tasks and interaction mode usually adopted, and finally a brief outline of main research findings. This is followed by a definition of dialogue, and how a dialogic approach to telecollaboration compares to the established models. This comparison is supported by the description of the Soliya Connect Program, the object of this research study. The author then describes a study which sought to answer the following research questions:

- How did participants evaluate this dialogic telecollaboration project?

- What was the role of facilitators perceived to be?

- What did participants see as the most important learning outcome of their participation in this project?

- Were there any differences between respondents from geographic regions (USA, Europe, Middle East and North Africa)

The research study adopted a survey methodology, with qualitative and quantitative data analysis. After discussing the findings and limitations of the study, the author reflects on whether this model could meet the need for 'purpose-driven language pedagogy as defined by Phipps and Levine (2010).

\section{Literature Review}

In language learning contexts, telecollaboration is "internet-based intercultural exchange between people of different cultural/national backgrounds set up in an institutional context with the aim of developing both language skills and intercultural communicative competence (as defined by Byram 1997) through structured tasks" (Guth \& Helm, 2010, p. 14). Telecollaboration is a form of network-based learning (Kern, Ware \& Warschauer, 2008) and has also been defined as internetmediated intercultural foreign language education (ICFLE) (Belz \& Thorne, 2006) and online intercultural exchange (O’Dowd, 2007). 
There are several different models of telecollaboration. The earliest models to be established, such as the Cultura model (Furstenberg, Levet, English \& Maillet, 2001; Bauer, de Benedette, Furstenberg, Levet \& Waryn, 2006) and institutional forms of Tandem learning (Kötter, 2003; O'Rourke, 2005) traditionally involve language learners in geographically distant locations engaging in bilateral, bilingual exchanges (Thorne, 2006). However, the implementation of online intercultural exchanges in a diversity of contexts has extended the scope of telecollaboration. New configurations of telecollaboration have been established involving different types of partners, for example trainee teachers (Belz \& Müller-Hartmann, 2003; Lee, 2006; Fuchs, 2007; Dooly \& Sadler, 2013), in-service teachers (Müller-Hartmann, 2006), Media or Communications students (O’Dowd, 2006; Schneider \& von der Emde, 2006) and also heritage speakers (Blake \& Zyzik, 2003). Exchanges may be multilateral, involving more than two groups in any one exchange (Müller-Hartmann, 2006; Hauck, 2007; Hauck \& Lewis, 2007) and they may involve global networks of learners (Guth, Helm \& O’Dowd, 2012). Exchanges are no longer necessarily bilingual, they can be multilingual, involving the sharing of more than two languages (Fratter, Helm \& Whigham, 2005), but often they are monolingual, involving just one of the partners' languages (Lee, 2006; O’Dowd, 2006) or the adoption of a lingua franca (Basharina, 2007; Guarda, 2013; Helm, Guth \& Farrah, 2012).

In most telecollaboration projects reported in the literature, teachers organize the communication and tasks, motivate students, monitor activities and provide feedback and support for learners, but usually learners engage in communication with one another, with no direct intervention from teachers in their interactions, whether they are communicating synchronously or asynchronously, in dyads, triads or having group discussions on fora. A wide variety of tools are available to learners for communication, from the more traditional tools such as e-mail and asynchronous discussion fora to Web 2.0 tools such as social networks, blogs, wikis (Dooly, 2008; Guth \& Thomas, 2010) and desktop video-conferencing (Develotte, Guichon \& Vincent, 2010). Communication can thus be asynchronous or synchronous, depending on objectives of the exchange and institutional and logistic constraints, such as different time zones, class times, teacher and/or student preferences. Each communication mode has its own characteristics and affordances for different activities and levels of language and intercultural learning. Asynchronous communication has the advantage of being space and time independent, and offers learners time to prepare their own and to reflect on and respond to others' interventions. Synchronous communication, on the other hand, and in particular video communication, offers immediacy and a higher degree of 'social 
presence', that is "the ability of participants in a community of inquiry to project themselves socially and emotionally as 'real' people (i.e., their full personality), through the media of communication being used" (Garrison, Anderson \& Archer, 2000, p. 94).

Objectives of telecollaboration depend on the project and the participant groups. They can include the development of language skills and/or intercultural communicative competence (Belz \& Thorne, 2006; O'Dowd, 2007; Dooly, 2008), development of new online literacies (Helm \& Guth, 2010), language tutoring skills (Mangenot \& Zourou, 2007), work-related competences such as translation and professional communication (Mousten, Maylath, Vandepitte \& Humbley, 2010). A recent survey of telecollaboration practitioners in Europe (Guth, Helm \& O'Dowd, 2012) revealed intercultural communicative competence (ICC) to be the most widely shared objective, confirming what Thorne (2010) describes as the 'intercultural turn' in foreign language education. Telecollaboration is ideal for the development of ICC, since it offers learners an authentic context for actually engaging in intercultural communication, overcoming what have been seen as the limitations of the classroom for intercultural learning (Belz, 2007). The definition of intercultural communicative competence which has been widely embraced in the telecollaboration literature is based on Byram's (1997) model. According to Byram

someone with some degree of intercultural competence is someone who is able to see relationships between different cultures - both internal and external to a society - and is able to mediate, that is interpret each in terms of the other, either for themselves or for other people. It is also someone who has a critical or analytical understanding of (parts of) their own and other cultures - someone who is conscious of their own perspective, of the way in which their thinking is culturally determined, rather than believing that their understanding and perspective is natural. (Byram, 2000 para. 9)

Research studies have reported on the many outcomes of different telecollaborative projects, such as gains in language development, accuracy and fluency (Kötter, 2003; Lee, 2006), intercultural communicative competence (Belz, 2007; Möllering \& Levy, 2012; O’Dowd, 2006), learner autonomy (O’Rourke, 2006), multimodal communicative competence (Hampel \& Hauck, 2006; Dooly \& Hauck, 2012). Research has also reported on the "difficulties, tension and failure" which, as Lamy and Goodfellow (2010) point out have been attributed to a wide range of factors, including socio-institutional constraints, differences in communication/negotiation/interactional 'styles', local learning values, and last "but not least incompatibilities in worldviews, for example about postcold-war Germany, about European anti-Americanism or about what counts as 'terrorism' in different hotspots of the world (Ware and Kramsch, 2005)" (Lamy \& Goodfellow, 2010, p. 110). 
Lamy and Goodfellow call into question several of the assumptions underlying the telecollaboration literature and argue, for instance, that the notion of 'intercultural' has been underconceptualised and that the ideologies of 'communicative competence' are more tied in with the utilitarian objectives of English Language Teaching in global English contexts and oriented towards the material success of individuals. There is, indeed, growing recognition that we need to critically re-assess our activity and better understand the situatedness of foreign language education, "the complex global and local relations of interwoven practices, policies and ideologies involving, among other factors, distance, historicity, power and control as well as inequalities generated by hierarchical ordering and classification" (Train, 2010, p. 144). An interdisciplinary approach which seeks to go beyond the binarism of "the either/or of bounded languages and identities - toward decolonial third spaces (Bhabha, 1994; Kramsch, 1993; Perez, 1999)" is invoked by Train (2010, p. 153), and many foreign language educators (see for example Kramsch, 2009; Dooly, 2011; Helm, Guth \& Farrah, 2012; Pegrum, 2009).

Drawing on theory from areas such as post-critical theory and critical pedagogy (Freire 1970), postcolonial (Spivak, 1999) and postmodern studies (Burbules \& Rice, 1991), cultural studies (Bhabha, 1994; Bakhtin, 1986) and peace studies (Lederach 1995), dialogic approaches have been developed and implemented in diverse educational settings in order to foster mutual understanding between diverse groups, or groups in conflict with one another (Nagda, Gurin \& Lopez 2003; Saunders, 2009; Andreotti, 2005). A more critical, dialogic approach could and should also be applied in foreign language education and telecollaboration, it is argued (Schneider \& von der Emde, 2006; Lamy \& Goodfellow, 2010; Phipps \& Levine, 2010), if more in-depth intercultural understanding is to be achieved. The rest of this paper focuses on dialogic approaches to learning. What is meant by dialogue? How has it been used in educational contexts and in telecollaboration? And finally the findings of a research study on the evaluation of the Soliya Connect Program, a dialogic telecollaboration project, will be presented and discussed.

\section{What is dialogue?}

According to Freire (1970),

Dialogue cannot be reduced to the act of one person's "depositing" ideas in another, nor can it become a simple exchange of ideas to be "consumed" by the discussants. Nor yet is it a hostile, polemical argument between those who are committed neither to the naming of the world, not to the search for truth, but rather to the imposition of their own truth. (p.70) 
Dialogue is not coercive or confrontational, rather it is a collaborative, mutual learning process with participants working together towards understanding. In dialogue, identities and difference are explored and personal experience and emotions contribute to awareness of self and others, and political understanding. Dialogue involves active listening to other perspectives. There is no single reality or truth, nor is there dualism with right and wrong answers but rather multiplicity and complexity. Dialogue entails critical thinking and aims to reveal assumptions and biases so they can be re-evaluated. Political correctness and politeness can be barriers to dialogue, the aim is for openness and sincerity and for exploration of the origins and personal meanings of perspectives.

In educational settings in which dialogue is used, power issues are acknowledged and openly addressed and conflict or dissensus is not avoided, rather it is seen as a natural social phenomenon and as key for learning to take place. Conflict is seen as a transforming agent, which can bring about systemic change. The notion of 'conflict transformation' (as opposed to conflict resolution, or conflict management), strongly influenced by the work of Paulo Freire,

encompasses a view that legitimizes conflict as an agent of change in relationships. [...] Transformation suggests a dynamic understanding that conflict can move in destructive or constructive directions, but proposes an effort to maximize the achievement of constructive, mutually beneficial processes and outcomes. (Lederach, 1995, p.19)

This view of conflict is alien to foreign language education, though the need for such an approach is beginning to be recognized. Phipps and Levine write

Conflict can occur anywhere where language is in play: domestically, intergenerationally, in diverse linguistic communities, ecologically, economically and politically. Each of these contexts, in a translingual world, requires language pedagogies that can rise to the challenges of conflict transformation because conflict transformation occurs in languages and is sensitive to language as potentially inflaming or transforming the injustice that leads to conflict. (2010, p.12)

Practical applications of the dialogic approach can be found outside of foreign language education (FLE) in various spheres (intergroup dialogue, development education, peace studies, social policy), but it is not a common approach in foreign language education, and even less so in telecollaboration, despite its proven potential for developing the kind intercultural awareness endorsed by the CEFR (2001), among other EU documents on language education.

Intergroup dialogue, for example, is an increasingly common activity on American university campuses that was established to create opportunities for students to actively learn from diversity in university classrooms and in the broader campus environment (Nagda, Gurin \& Lopez 2003; Nagda, Gurin, Sorensen \& Zúñiga 2009;). Research carried out by Nagda et al. has found that 
Through sustained dialogue with diverse peers that integrates content learning and experiential knowledge, intergroup dialogue encourages students to be intellectually challenged and emotionally engaged. These facilitated relationships influence students' understanding of their own and others' experiences in society and cultivate individual and collective agency to effect social change. $(2009$, p. 6)

The sustained dialogue approach (Saunders, 1999), which shares commonalities with intergroup dialogue is extensively used across campuses in the US and also by citizen groups. Development education is another area where a dialogic approach has been established in response to dissatisfaction with public perceptions of and attitudes to development which are based on compassion and charity (Andreotti \& de Souza, 2008). The aim of introducing a dialogic approach stemmed from the belief that

Addressing complexity, understanding interdependence and learning to question and use different modes of thinking may help learners see themselves as integral to the picture they are trying to change (both as part of the problem and the solution) and prevent the reproduction of mechanisms that generate or maintain the problems that are addressed. (Andreotti, 2005, p. 1)

In the following section a dialogic telecollaboration project, the Soliya Connect Program which also shares a number of these characteristics is described.

\section{The Soliya Connect Program - a situated, dialogic learning model}

The Soliya Connect Program (henceforth SCP) is a 9-week telecollaboration project which most participants take part in as an element of their university courses which range from political science, international relations, media studies but also English language programs. The Connect Program comprises several different elements, the main one being a weekly video-conferencing session in a dialogue group of 7-9 participants led by two trained facilitators on issues which are seen to be divisive. 


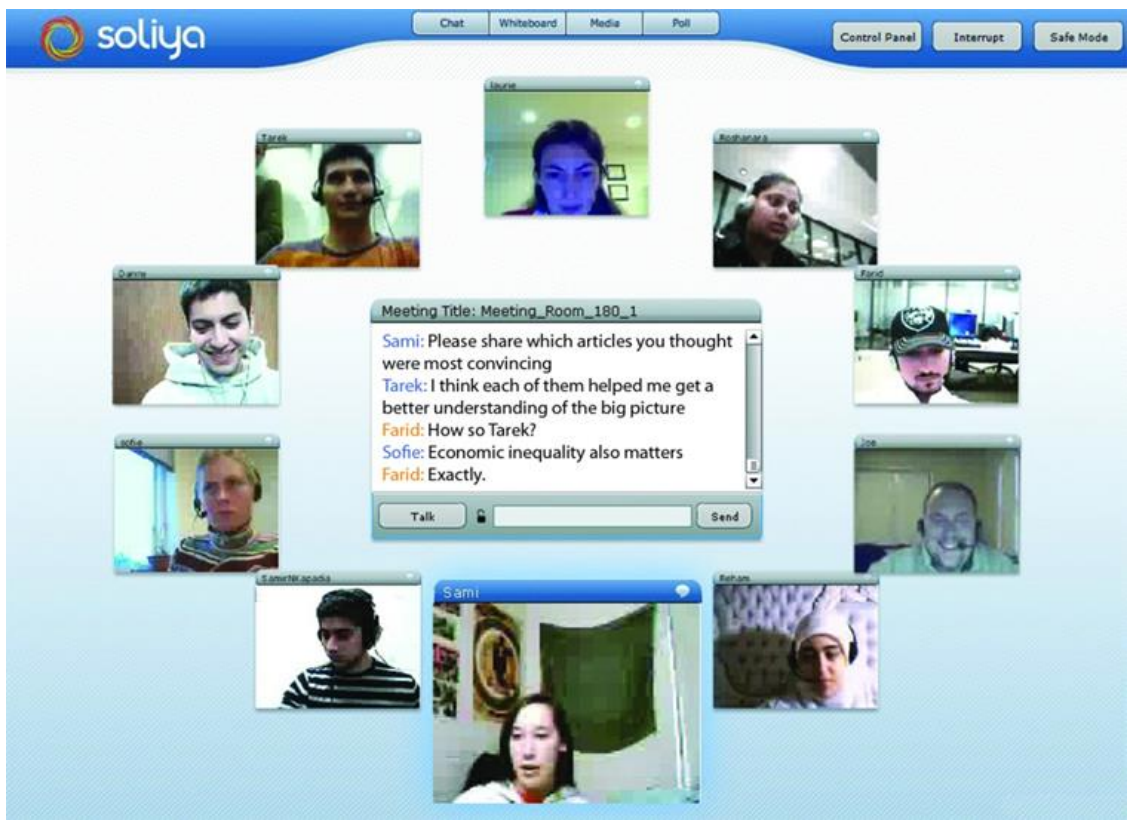

Figure 1. The Soliya videoconferencing interface (image and permission to publish granted by Soliya)

What is characteristic of the software Soliya has developed is the way participants are arranged in a circle, which creates a friendly non-threatening environment that has affinities to the seating arrangement used for university seminars, 'circle time' in primary schools, therapy groups and is more conducive to dialogue as everybody (apparently) has equal status.

Each iteration of Soliya has over 200 participants and over 30 dialogue groups. All dialogue groups follow a shared online curriculum, which has a clear structure and progression, from getting to know each other, to defining global challenges and topics for discussion to reflection and planning for action. There are some tasks which all groups are required to do, and others which the facilitators who plan and lead sessions can choose from the curriculum Soliya provides for each week. Some weeks all groups discuss the same topics which are key to the SCP curriculum, such as the relationship between Western and predominantly Muslim societies, the role of religion in society, stereotypes, the role of the media, the situation in Palestine and Israel, other weeks the groups establish topics for discussion. The required activities are:

- $\quad$ assigned readings and discussions based on these;

- individual production of a short video;

- discussion in pairs or groups of 3 in break out rooms for part of one or two sessions.

Participants also have their own blog in the Soliya community which they can use to communicate with the extended Soliya community, that is all the students participating in the other dialogue groups during that time, as well as Soliya alumni, facilitators and trainers.

As in all of the dialogue practices discussed in the previous section, the facilitator plays a 
key role in the SCP, and is essential to the success of the project. The facilitators lead the dialogue groups, structuring sessions, offering ice-breaker activities and helping participants gradually get to know each other and begin to take possession of the dialogue process. Facilitators have many different skills which they need to put into play, such as active and empathetic listening; asking good questions, avoiding questions that reveal bias and asking questions that will push the conversation to a deeper level; help participants recognize assumptions; reflect on the content and process of the dialogue sessions with the group (Soliya, 2010). The project is set up so that facilitators in each dialogue group are paired, where possible there is one from the Western world and another from the predominantly Muslim world and preferably is an Arabic speaker. Facilitators also have a coach whose role is to provide advice and support for them and observe one of their sessions, providing them with feedback and opportunities for developing and improving their skills.

The Soliya Connect Program was not developed as an English Language program, but has been adopted in advanced English language courses in various institutes in Europe and the Middle East. The rationale for this is that it is a form of experiential learning, or what could also be considered CLIL (Content and Language Integrated Learning) learning, in which learners are required to use English as a vehicular language to learn more about international relations, issues that divide the Western and Arab/Muslim world. As well as the knowledge component, the Soliya Connect Program enhances the development of intercultural competence and also new online literacies, such as communicating in synchronous online video, using text and audio chat simultaneously, multi-tasking, and video production skills. At the same time SCP allows learners to develop their critical thinking and critical literacies as they are encouraged to question assumptions, power relations and representation and also develop reflexivity.

\section{How does a dialogic model of telecollaboration differ from traditional models?}

The SCP is what I would define as a dialogic model of telecollaboration, and differs from traditional models in several ways, as summarized in Table 1, below.

Table 1. Differences between 'traditional' models of telecollaboration and a dialogic model

\begin{tabular}{l|l}
\hline \multicolumn{1}{c|}{ 'Traditional' models of telecollaboration } & \multicolumn{1}{c}{ 'Dialogic' telecollaboration } \\
\hline $\begin{array}{l}\text { Communication is often in dyads or triads, (with the } \\
\text { exception of asynchronous forum discussions) }\end{array}$ & Communication is in groups of 6+ students \\
\hline $\begin{array}{l}\text { Students engage in discussion with peers without the } \\
\text { presence of teacher or facilitators }\end{array}$ & $\begin{array}{l}\text { Students engage in dialogue sessions led by } \\
\text { trained facilitators }\end{array}$ \\
\hline $\begin{array}{l}\text { Participants should feel comfortable in their } \\
\text { communication }\end{array}$ & $\begin{array}{l}\text { Participants are gradually taken out of their } \\
\text { comfort zones }\end{array}$ \\
\hline $\begin{array}{l}\text { 'Safe' topics tend to be discussed, such as university } \\
\text { or student life, culture, free time. Contentious issues } \\
\text { are avoided. }\end{array}$ & $\begin{array}{l}\text { Divisive topics and conflicting world views are } \\
\text { deliberately addressed }\end{array}$ \\
\hline
\end{tabular}




\begin{tabular}{l|l}
\hline $\begin{array}{l}\text { Students are expected to be 'polite' and 'politically } \\
\text { correct' }\end{array}$ & $\begin{array}{l}\text { Politeness and political correctness are seen as } \\
\text { barriers to dialogue }\end{array}$ \\
\hline $\begin{array}{l}\text { Synchronous or asynchronous, written and oral } \\
\text { communication modes can be used }\end{array}$ & Synchronous video communication is preferable \\
\hline Disagreement is accepted but conflict is avoided & $\begin{array}{l}\text { Conflict is seen to be potentially constructive } \\
\text { and can lead to transformation }\end{array}$ \\
\hline
\end{tabular}

In order to be exposed to a multiplicity of diverse viewpoints participants do not engage in dyadic communication, but rather group interactions. Since the dialogic approach aims to address divisive issues, inequalities and imbalances of power, a 'safe' environment where participants trust one another needs to be created, hence the need for trained facilitators to lead the discussions and create this kind of space. As venturing onto any online news discussion forum on a contentious issue will reveal, dialogue and understanding do not seem to occur when participants do not 'listen' to one another or seek to explore the motivations behind the opinions. When students are interacting without mediation it is unadvisable for them to address divisive issues, since communication can easily break down if the conditions have not been created for engagement in dialogue. Most telecollaboration projects reported in the literature tend to have students discussing 'safe' topics in order to avoid this communication breakdown, yet, as some scholars have reported (Helm \& Guth, 2010; Schneider \& von der Emde, 2006), it can be difficult for participants to move beyond information exchange and superficial cultural comparison and reach deeper levels of understanding. The use of synchronous video communication is important for effective dialogue since it offers an appropriate level of social presence to enhance interpersonal involvement and engagement, offering participants' insight into each other's emotions and reactions.

\section{Research questions, methodology and data analysis}

The aim of this study was to answer the following research questions:

- How do participants in the Soliya Connect Program evaluate their experience of dialogic telecollaboration?

- How essential is the role of facilitators perceived to be in creating a dialogic space?

- What do participants in the SCP see as the most important learning outcome of their participation in this dialogic telecollaboration project.

- Are there any differences in responses from participants in the three broad geographic regions?

The data for this study come from a post-SCP survey designed and carried out by the organization, Soliya, at the end of the 2010 Spring iteration of SCP. The survey consists of both quantitative Likert scale items and open questions. For the purposes of this paper a selection of the closed items (see Annex 1) and one open question, "What was the most important thing(s) that you learned 
through your participation in the Soliya Connect Program?" were analysed. The researcher ${ }^{1}$ was provided with all the responses to the questionnaire which had been anonymized by Soliya.

In Spring 2010, 275 students from 35 different universities (student numbers per university ranged between 1 and 24) and studying in various degree courses from Political Science to Media Studies, Conflict Resolution and English Language, were enrolled in the program. There were 145 students from the predominantly Muslim world, 75 from the US, 57 from Europe (Amsterdam, Brussels and Padova), so in general there was a fairly equal balance between 'Western' and predominantly Muslim and Arab students. These students were split into 34 different groups with, as far as possible, equal representatives from the two different 'regions' of the program - generally 4 from the 'Western' world and 4 from the predominantly Muslim world. 217 students completed the post-SCP survey, which makes for nearly an $80 \%$ response rate, and this is the data which is considered in the following section.

The quantitative data were analysed using statistical methods with a comparison of responses across three groups of participants: US, Europe, the Middle East and North Africa. For each of the closed items in the survey a mean score was calculated for each regional group and for all participants. To compare the evaluations of the Connect program by participants in the different regional groups, the difference between the mean for each group versus all the other groups was calculated using a F-Fisher test (which calculates between groups /within groups variability) and significance was calculated at 5\%. The qualitative data, responses to the open question, were analysed and coded manually by the researcher and two fellow researchers. Coding categories were defined and are included in Annex 2 with examples for each category.

\section{Findings and Discussion}

\section{Positive evaluation of the dialogic model}

The overall evaluation of the SCP was extremely high (see Annex 1). Virtually all students were glad they participated in SCP and said they would recommend it to their peers. Students reported having built meaningful relationships through participation and that it had helped them clarify what they feel about issues that are important to them, with most of them indicating that they were motivated to learn more about the relationship between the West and the Muslim world and also empowered in feeling they would play a larger role in informing their peers about these issues. The regional group which evaluated the project most highly all round was the Arab/Muslim group, with a significantly higher mean score than all of the other groups on most of the survey questions. 
Only 17 students out of 217 evaluated the project somewhat negatively ( 3 out of 5 or less on Likert Scale), but these negative evaluations were not limited to a particular dialogue group or to students from a particular region, they were distributed across all regions suggesting that the dialogic approach adopted was not dispreferred by any broad cultural group or any one of the specific dialogue groups, but these negative evaluations were due to individual characteristics.

\section{Importance of facilitators and the creation of a safe, dialogic space}

Of all the different components of the SCP, (the blog, video project, lectures in their respective classes, readings) it was the dialogue sessions which were recognized as contributing most to the respondents' learning experience. Respondents rated the effectiveness of their facilitators very highly, and also the level of trust and safety to speak openly in the group. In the responses to the open questions, several students from the predominantly Arab and Muslim regions reported that the most important thing they had learnt was to express themselves freely and openly. For students from this region, the facilitators were reported to be particularly important in encouraging them to speak more, and more openly, and also in helping them make themselves understood, as this remark indicates:

\section{Extract 1. Response to open-ended question}

"because in many times students were not able to express there ideas in English and sometimes differences in our accent would not let us understand will but we easily overcame that because of the amazing facilitators we had such as Emma "the English version of my mind" and Fatima "she types just what we wonna say" :P"

The fact that the facilitators were more strongly appreciated by participants in the Middle East than in the US perhaps reflects how they compensated for the possible inequalities in participants' English language competence and their not necessarily being used to speaking freely and openly in a semi-academic context.

Many respondents from both US and Arab and Muslim regions also commented on how the dialogue sessions offered them the opportunity to learn to 'listen' to other views, which is a key to dialogue. A considerable number of respondents also highlighted the importance of dialogue with others in order to learn more, to understand other views better and also to understand how others view your cultures. Disagreement and conflict were mentioned by several participants, but never in a negative light, but rather as an opportunity for learning more, as illustrated in this comment.

\section{Extract 2. Response to open-ended question}

"I was fortunate enough to have a very diverse group that was vocal about their opinions, and I think really being able to discuss important issues with them in an open 
environment gave me a lot of insight in to how and why people think and act the way they do."

This too is a reflection of the success of the dialogic approach adopted, for conflict is not seen as a negative or threatening experience, but rather as an opportunity for learning.

\section{Challenging stereotypes and media representations through dialogue with 'real' people}

In responses to the open question, many of the respondents indicated that the most important thing they learnt was not to make generalizations or to judge people without getting to know them and asking questions. An increased awareness of media representations and how media stereotypes can lead to prejudice emerged quite strongly.

\section{Extract 3. Response to open-ended question}

"I learned that you cannot blindly trust the media. Now I do my own research about topics, looking at various viewpoints and sources before forming an opinion."

Actually engaging in communication and dialogue with people from parts of the world they had previously known mainly or exclusively through the media had an important impact on several participants and led them to re-evaluate some of the biases they may have had. Only in a very small number of responses did stereotypes seem to have been reinforced.

What is repeated in many of the responses to open questions is the emphasis on the human element, the 'real people' that participants can see, hear and talk to through the dialogue sessions, even if this communication occurs at a distance, mediated by technology. The use of videoconferencing technology clearly has a strong impact on participants' perception of social presence, more so than asynchronous communication would have done. This human dimension is important because, as Ess (2009) writes, "when we deal with one another as embodied beings [...] we engage with one another as distinctive human beings first, not simply as tokens for overly simple and overly generalized accounts of cultures and subcultures" (p. 29).

\section{Variation in focus on difference and/or similarities}

Among the most frequent words to appear in the responses to the open question were other/others, different/differences, which were usually followed by words such as opinions, cultures and view. Same and common also appeared among the most frequent words, but with less frequency. In manually coding the responses to the open questions two different categories were developed, one 
with a focus on differences and learning to see, understand, accept and respect differences of opinion, culture and beliefs. The other category regarded a focus on similarities, though acknowledgement of difference may have been present in the response ${ }^{2}$.

Table 2. Frequency of codes: similarity and difference

\begin{tabular}{l|l|l|l}
\hline Code & US & Europe & Middle East and North Africa \\
\hline $\begin{array}{l}\text { Similarities } \\
\text { Focus on similarities, though differences } \\
\text { may be acknowledged }\end{array}$ & $42 \%$ & $22 \%$ & $10 \%$ \\
\hline $\begin{array}{l}\text { Difference } \\
\begin{array}{l}\text { Focus on accepting and respecting } \\
\text { different opinions and points of view } \\
\text { (tolerance, respect, dignity) }\end{array}\end{array}$ & $2 \%$ & $16 \%$ & $20 \%$ \\
\hline
\end{tabular}

Responses were also compared across regional groups, and it was found that over $40 \%$ of the US students emphasized commonalities in their open answers while $2 \%$ focused on difference.

\section{Extract 4. Response to open-ended question}

"I learned how alike we really are. I take for granted living in a small town all of my life. I just assumed that everyone else must be different than me especially when they live on the other side of the world. Instead, I realized how much I had in common with a Girl from Italy and then a girl from Jordan. It was amazing."

European students did not focus quite so much on similarities, there was a more equal distribution with some respondents emphasizing difference and the importance of respect for difference and the importance of dignity, others highlighted similarities. Respondents from the Middle East and North Africa on the other hand mentioned difference more often than similarity, and said they had learnt to understand, respect and tolerate different opinions.

\section{Extract 5. Response to open-ended question}

"one of the most important things I learned is that often people have different opinions because they have different historical experiences than others do. So people in the Middle East will remember certain events differently than people in the West, and this will color their perceptions differently as well..."

Various interpretations of this are possible, since we could consider that the US students perhaps began with the exchange with expectations of a huge cultural gap and were surprised that it was not as great as they expected, as was specified in some of the students' responses to the open question. These results could also be indicative of power asymmetries on the macro-level. Research in conflict resolution and power dynamics has demonstrated that dominant groups tend to minimalize inter-group difference. Agbaria and Cohen (2000) in their research on conflict management report that 'advantaged' groups tend to emphasize common humanity and building friendships. Several 
respondents mentioned a greater understanding of the complexity of the relationship between the Western and predominantly Arab and Muslim world, the difficulties of communication and the challenges of diplomacy. Some mentioned how much they still need to learn, and a strong desire to learn more.

\section{Conclusion}

The research study has some limitations. Self-reporting is not considered hard scientific evidence for learning and demonstrating the effectiveness of a pedagogic approach, whether dialogic or any other, would require support from more objective measures. There is also a clear need to obtain data from the dialogue sessions themselves, and observe 'dialogue in action' as it were. However student perceptions are of value since attitude and motivation are key to learning.

What this study has shown though is that SCP is a dialogic model of learning in which participants feel they develop greater understanding of different opinions and viewpoints, and which makes them recognize the need for dialogue and communication with 'real' people in order to challenge the stereotypes that are promulgated, particularly through the media. In these dialogue sessions, differences are not minimized and unlike most established telecollaboration models, conflict is not avoided. However what is important is that this occurs in a safe space, many of the participants reported feeling free to express themselves openly and being comfortable with disagreements in the group and appreciating different opinions. The facilitators played a crucial role in creating this secure environment, and this was acknowledged by the participants. Facilitators are necessary in creating equality in participation by leading discussions, particularly in initial phases, by encouraging and supporting those with technical and linguistic difficulties in making themselves understood, helping to balance the possible power inequalities as far as language competence and free expression is concerned. If there are no facilitators, it is difficult, if not impossible for this kind of dialogue to take place. The use of video-conferencing is also a key factor since it offers a high level of social presence, immediacy and intimacy which allow participants to see each other as human beings and individuals, with emotions and needs.

Dialogic telecollaboration projects like the Soliya Connect Program offer a valid pedagogic approach which responds to the Council of Europe's call for educators to engage students in intercultural dialogue (2008) by offering language learners the opportunity to engage with multiple subjectivities and perspectives in a safe environment where they are free to dig deeper to acquire intercultural understanding. The absence of dialogue, the Council of Europe warns, "deprives everyone of the benefit of new cultural openings, necessary for personal and social development in 
a globalised world" (2008, p.16).

\section{References}

Agbaria, F., \& Cohen, C. (2000). Working with groups in conflict: The impact of power relations on the dynamics of the group. Informally published article, Waltham, MA: Brandeis University. Retrieved from http://www.brandeis.edu/ethics/pdfs/publications/Working_Groups.pdf

Andreotti, V. (2005). Briefing. Open spaces for dialogue and enquiry methodology. Retrieved on 20 January 2013 from http://www.osdemethodology.org.uk/keydocs/osdebriefing.pdf

Andreotti, V., \& de Sousa, L.M. (2008). Translating theory into practice and walking minefields: lessons from the project 'Through other eyes'. International journal of development education and global learning, 1(1): 23-36.

Bakhtin, M. (1986). Speech genres and other late essays. Austin, TX: University of Texas Press.

Basharina, O.K. (2007). An activity theory perspective on student-reported contradictions in international telecollaboration. Language learning \& technology, 11(2): 82-103. Retrieved 29 July 2009 from <http://ltt.msu.edu/vol11num2/basharina/ default.html>.

Bauer, B., deBenedette, L., Furstenberg, G., Levet, S., \& Waryn, S. (2006). The Cultura project. In: J.A. Belz. and S. Thorne (Eds.), Internet-mediated intercultural foreign language education, (pp. 31-62). Boston: Thomson Heinle.

Belz, J. (2007). The development of intercultural communicative competence in telecollaborative partnerships. In R. O'Dowd (Ed.) Online intercultural exchange: An introduction for foreign language teachers (pp. 127-166). Clevedon: Multilingual Matters

Belz, J.A., \& Müller-Hartmann, A. (2003). Teachers as intercultural learners: Negotiating GermanAmerican telecollaboration along the institutional fault line. The modern language journal, 87(1): 71-89.

Belz, J.A. \& Thorne, S.L. (2006). Introduction. In: J.A. Belz \& S. Thorne (Eds.) Internet-mediated intercultural foreign language education ( $\mathrm{pp}$. viii-xxv). Boston: Thomson Heinle.

Bhabha, H. (1994). The location of culture. London, Routledge

Blake, R.J., \& Zyzik, E.C. (2003). Who's helping whom?: Learner/heritage-speakers' networked discussions in Spanish. Applied linguistics, 24(4): 519-544.

Burbules, N. C. (2006). Rethinking dialogue in networked spaces. Cultural Studies \& Critical Methodologies, 6: 107-122.

Burbules, N. C., \& Rice, S. (1991). Dialogue across difference: Continuing the conversation. Harvard Educational Review, 61: 393-416.

Byram M. (2000). Assessing intercultural competence in language teaching. Sprogforum 18 (6): 8 13. Retrieved on 20 January 2013 from http://inet.dpb.dpu.dk/infodok/sprogforum/Espr18/byram.html

Byram, M. (1997). Teaching and assessing intercultural communicative competence. Clevedon: Multilingual Matters.

Council of Europe (2008). White paper on intercultural dialogue. Living together as equals in dignity. Strasbourg: Council of Europe. Retrieved on 20 January 2013 from http://www.coe.int/t/dg4/intercultural/source/white\%20paper_final_revised_en.pdf

Develotte, C., Guichon, N., \& Vincent, C. (2010). The use of the webcam for teaching a foreign language in a desktop videoconferencing environment. ReCALL, 22: 293-312.

Dooly M. (2008). Telecollaborative language learning. Bern: Peter Lang.

Dooly M. (2011). Crossing the intercultural borders into 3rd space culture(s): implications for teacher education in the twenty-first century, Language and intercultural communication, 11(4), 319-337. 
Dooly, M., \& Hauck, M. (2012). Researching multimodal communicative competence in video and audio telecollaborative encounters. In M. Dooly \& R. O’Dowd (Eds.) Researching online foreign language interaction and exchange (pp.135-162). Bern: Peter Lang.

Dooly, M., \& Sadler, R. (2013). Filling in the gaps: Linking theory and practice through telecollaboration in teacher education. ReCALL, 25: 4-29.

Ess, C. (2009). When the solution becomes the problem: cultures and individuals as obstacles to online learning. In R. Goodfellow \& M.N.Lamy (Eds.) Learning cultures in online education (pp.15-29). London: Continuum.

European Council (2001). The common european framework of reference for languages: learning, teaching, assessment (CEFR). Cambridge: Cambridge University Press.

Fratter, I., Helm, F., \& Whigham, C. (2005). Cross-cultural exchanges at the language centre of the University of Padua and the issue of language. In: A. Moraviková ${ }_{2}$ C. Taylor Torsello \& T. Vogel (Eds.), Proceedings of the $8^{\text {th }}$ CercleS conference: University language centres: Broadening horizons, expanding networks (pp. 177-195). Bratislava: CercleS.

Freire, P. (1970/1996). The pedagogy of the oppressed. London: Penguin.

Fuchs, C. (2007). Pre-service teachers as intercultural learners in CMC-based collaboration: the case of the literature group. Journal of Intercultural Communication, 13. Retrieved on 20 January 2013 from http://www.immi.se/intercultural/nr13/fuchs.htm

Furstenberg, G., Levet, S., English, K. \& Maillet, K. (2001). Giving a voice to the silent culture of language: The CULTURA Project. Language Learning \& Technology, 5(1): 55-102.

Retrieved 29 July 2009 from <http://llt.msu.edu/vol5num1/furstenberg/ default.html>.

Garrison, D.R., Anderson, T. \& Archer, W. (2000). Critical inquiry in a text-based environment: Computer conferencing in higher education. The Internet and Higher Education, 2(2-3): $87-105$.

Guarda, M. (2013). Negotiating a transcultural place in an English as a lingua franca telecollaboration exchange: a mixed methods approach to the analysis of intercultural communicative competence and third space in an online Community of Practice. Unpublished Phd thesis, University of Padova.

Guth, S. \& Helm, F. (2010). Introduction. In S. Guth \& F. Helm (Eds.), Telecollaboration 2.0: Language, literacy and intercultural learning in the 21 st century (pp. 69-106). Bern: Peter Lang.

Guth, S., Helm F., \& O'Dowd, R. (2012). University language classes collaborating online. A report on the integration of telecollaborative networks in European universities. Retrieved on 20 January 2013 from http://intentproject.eu/sites/default/files/Telecollaboration_report_Final_Oct2012.pdf

Guth, S., \& Thomas, M. (2010). Telecollaboration with web 2.0 tools. In S. Guth \& F. Helm (Eds.), Telecollaboration 2.0: Language, literacy and intercultural learning in the 21 st century, (pp. 69-106). Bern: Peter Lang.

Hampel, R., \& Hauck, M. (2006). Computer-mediated language learning: Making meaning in multimodal virtual learning spaces, The JALT CALL Journal, 2 (2), 3-18.

Hauck, M. (2007). Critical Success Factors in a TRIDEM Exchange. ReCALL, 19(2): 202-223.

Hauck, M., \& Lewis, T. (2007). The Tridem project. In: R. O'Dowd (Ed.) Online intercultural exchange: an introduction for foreign language teachers (pp. 250-258). Clevedon: Multilingual Matters.

Helm, F., \& Guth, S. (2010). The multifarious goals of telecollaboration 2.0: Theoretical and practical implications. In S. Guth \& F. Helm (Eds.) Telecollaboration 2.0: Language, literacy and intercultural learning in the 21st century (pp. 69-106). Bern: Peter Lang. 
Helm F., Guth S., \& Farrah M. (2012). Promoting dialogue or hegemonic practice: Power issues in telecollaboration, Language Learning \& Technology, 16(2): 103-127.

Holliday, A. (2006). Key concepts in ELT. Native-speakerism, ELT Journal, 60(4): 385-387.

Kern, R., \& Warschauer, M. (2000). Network-based language teaching: Concepts and practice.

New York: Cambridge University Press.

Kern R., Ware P., \& Warschauer, M. (2008). Network-based language teaching. In N. Van DeusenScholl \& N. H. Hornberger (Eds.) Encyclopedia of language and education, 2nd Edition, Volume 4: Second and Foreign Language Education, (pp. 281-292). New York: Springer.

Kötter, M. (2003) Negotiation of meaning and codeswitching in online tandems. Language Learning \& Technology, 7(2): 145-172.

Kramsch, C. (1993). Context and culture in language teaching. Oxford: Oxford University Press.

Kramsch C. (2009). Third culture and language education. In V. Cook \& L. Wei (Eds.) Contemporary applied linguistics (pp. 233-254). London: Continuum.

Lamy, M-N., \& Goodfellow, R. (2010). Telecollaboration and learning 2.0. In S. Guth \& F. Helm (Eds.) Telecollaboration 2.0: Languages, literacies and intercultural learning in the 21st century (pp. 107-138). Bern: Peter Lang.

Lederach, J.P. (1995). Preparing for peace. New York: Syracuse University Press.

Lee, L. (2006). A study of native and nonnative speakers' feedback and responses in SpanishAmerican networked collaborative interaction. In: J.A. Belz \& S.L.Thorne (Eds.) Internetmediated intercultural foreign language education (pp. 147-176). Boston: Thomson Heinle.

Mangenot, F., \& Zourou, K. (2007). Pratiques tutorales correctives via Internet: le cas du français en première ligne. ALSIC, 10 (1). Retrieved October 15, 2007 from http://alsic.revues.org/650

Möllering, M., \& Levy, M. (2012). Intercultural competence in computer-mediated communication: An analysis of research methods. In M. Dooly \& R. O’Dowd (Eds.) Researching online foreign language interaction and exchange (pp.135-162), Bern: Peter Lang.

Mousten, B., Maylath, B., Vandepitte, S., \& Humbley, J. (2010). Learning localization through trans-atlantic collaboration: Bridging the gap between professions. IEEE Transactions on professional communication, 53(4), 401-411.

Müller-Hartmann, A. (2006). Learning how to teach intercultural communicative competence via telecollaboration: A model for language teacher education. In: J.A. Belz \& S.L. Thorne (Eds.) Internet-mediated intercultural foreign language education (pp. 63-84). Boston: Thomson Heinle.

Nagda, B. A., Gurin, P., \& Lopez, G. E. (2003). Transformative pedagogy for democracy and social justice. Race ethnicity \& education, 6(2), 165-191.

Nagda, B.A., Gurin, P., Sorensen, N., \& Zúñiga, X. (2009). Evaluating intergroup dialogue:

Engaging diversity for personal and social responsibility. Diversity \& democracy, 12(1): 4-

6. Retrieved on 20 January 2013 from http://igr.umich.edu/files/igr/Evaluating\%20Intergroup\%20Dialogue.pdf

O'Dowd, R. (2006). Telecollaboration and the development of intercultural communicative competence. Berlin: Langenscheidt.

O'Dowd, R. (Ed.) (2007). Online intercultural exchange: An introduction for foreign language teachers. Clevedon: Multilingual Matters.

O'Dowd, R., \& Ritter, M. (2006). Understanding and working with 'failed communication' in telecollaborative exchanges. CALICO Journal, 61(2): 623-642.

O'Dowd, R., \& Ware, P. (2009). Critical issues in telecollaborative task design, Computer Assisted Language Learning, 22(2):173-188. 
O'Rourke, B. (2005). Form-focused Interaction in online tandem learning. CALICO Journal, 22(3): 433-466.

Pegrum, M. (2009). Seeking a third space in intercultural education: What discourse analysis tells us. Opening plenary at Cutting Edges 2009: Discourse, context and language education, University of Canterbury Christ Church, UK, 25-27 June.

Phipps, A., \& Levine, G.S. (2010). What is language pedagogy for? In G. Levine \& A. Phipps, (Eds.) Critical and intercultural theory and language pedagogy (pp.1-14). Boston: Cengage Learning.

Saunders, H. (1999). A public peace process: Sustained dialogue to transform racial and ethnic conflicts. New York: Martin's Press.

Schneider, J., \& von der Emde, S. (2006). Conflicts in cyberspace: From communication breakdown to intercultural dialogue in online collaborations. In J.A. Belz \& S.L. Thorne (Eds.) Internet-mediated intercultural foreign language education (pp. 178-206). Boston: Thomson Heinle Publishers.

Soliya, (2010). Connect program facilitation training guide. Fall 2010. Unpublished training manual.

Spivak, G. (1999). A critique of postcolonial reason: toward a critique of the vanishing present. Cambridge MA: Harvard University Press.

Thorne, S.L. (2006). Pedagogical and proxiological lessons from internet-mediated intercultural foreign language education research. In: J.A. Belz \& S.L. Thorne (Eds.) Internet-mediated intercultural foreign language education (pp. 2-30). Boston: Thomson Heinle.

Thorne, S.L. (2010). The 'intercultural turn' and language learning in the crucible of new media. In S. Guth \& F. Helm F (Eds.) Telecollaboration 2.0: language, literacies and intercultural learning in the 21 st century (pp. 139-164). Bern: Peter Lang.

Train, R. (2010). Postcolonial complexities in foreign language education and the humanities. In G. Levine \& A. Phipps (Eds.) Critical and intercultural theory and language pedagogy (pp.141-160). Boston: Cengage Learning.

Ware, P., \& Kramsch, C. (2005). Toward an intercultural stance: Teaching German and English through telecollaboration. Modern Language Journal, 89(2), 190-205.

\section{Acknowledgements}

The author would like to thank the anonymous peer reviewers for feedback on the original submission. She would also like to express thanks to Soliya for their support and for sharing their data; Paola Bolzonello for support in the statistical analysis; Sarah Guth and Marta Guarda in coding and discussing the data.

\footnotetext{
Author's Reference:

Francesca Helm is a researcher at the Department of Politics, Law and International Studies at the University of Padova. She teaches English to students on second-level degree courses in International Politics and Diplomacy, European Studies. Her research interests lie in the areas of intercultural dialogue, telecollaboration, learner identity, the socio-cultural context of Web 2.0 for language and intercultural learning, new online literacies and the use of English in global communication. She has been a facilitator for Soliya and is currently a coach in the Soliya Connect Program. She is currently working on a PhD at the Universitat Autonoma de Barcelona.
}

Email: francesca.helm@unipd.it

To cite this article:

Helm, F. (2013). A dialogic model for Telecollaboration. Bellaterra Journal of Teaching \& Learning Language \& Literature, 6(2), 28-48. 


\footnotetext{
${ }^{1}$ Note on researcher's role. The author of the paper is an English language teacher and researcher of language teaching and particularly telecollaboration. She has been involved in the Soliya Connect Program on a voluntary basis since 2009 in various guises, first of all and still now as a university teacher with students participating in the SCP, subsequently as a trainee facilitator, a facilitator and now as a coach for facilitators. The data for this study were kindly provided to the author by Soliya.

${ }^{2}$ The words different and difference actually appeared more frequently than the words same and similar, but differences was not the most frequent coding category. This can be explained by the fact that respondents who focused on similarities often mentioned difference.
}

\section{Annex 1}

Responses to post-survey questions with means compared across regions. Respondents were asked to rate their agreement with statements on a scale from 1 to 5.

\begin{tabular}{|l|l|l|l|l|}
\hline & $\begin{array}{l}\text { Total } \\
\text { Mean }\end{array}$ & MENA & Europe & US \\
\hline $\begin{array}{l}\text { D20 While participating in the Soliya Connect Program, I shared } \\
\text { information about what I was learning with my peers and other } \\
\text { people in my community }\end{array}$ & 4,17 & $4,30^{*}$ & 4,02 & 4.04 \\
\hline $\begin{array}{l}\text { D22 The Soliya Connect Program motivated me to learn more about } \\
\text { the relationship between the West and the Muslim World }\end{array}$ & 4,23 & 4,28 & 4,15 & 4,13 \\
\hline $\begin{array}{l}\text { D23 I believe I will play a larger role in informing my peers about the } \\
\text { relationship between the West and the Muslim World as a result of } \\
\text { the Soliya Connect Program }\end{array}$ & 4,00 & $4,14^{*}$ & 3,53 & 3,98 \\
\hline $\begin{array}{l}\text { D24 I built meaningful relationships through my participation in the } \\
\text { Soliya Connect Program }\end{array}$ & 3,96 & $4,17^{*}$ & 3,53 & 3,87 \\
\hline $\begin{array}{l}\text { D25 Participating in the Soliya Connect Program helped me clarify } \\
\text { what I think and feel about issues that are important to me }\end{array}$ & 4,03 & $4,25^{*}$ & 3,62 & 3,93 \\
\hline $\begin{array}{l}\text { D26 I am glad that I chose to participate in the Soliya Connect } \\
\text { Program }\end{array}$ & 4,53 & $4,65^{*}$ & 4,36 & 4,39 \\
\hline D27 I would recommend the Soliya Connect Program to my peers & 4,42 & 4,53 & 4,23 & 4,31 \\
\hline D28 How would you rate the effectiveness of your facilitators? & 4,34 & $4,47^{*}$ & 4,17 & 4,18 \\
\hline $\begin{array}{l}\text { D31 How would you rate the contribution of the real-time dialogue } \\
\text { sessions to your learning experience? }\end{array}$ & 4,10 & 4,11 & 3,96 & 4,18 \\
\hline $\begin{array}{l}\text { D32 How would you rate the level of trust and safety to speak openly } \\
\text { in your online group? }\end{array}$ & 4,24 & 4,33 & 4,17 & 4,07 \\
\hline
\end{tabular}

* significant difference calculated at $5 \%$ with an F Fisher test.

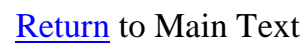

\section{Annex 2}

Codes, descriptions and examples from analysis of responses to the question

\begin{tabular}{|l|l|l|}
\hline CODE & DESCRIPTION & EXAMPLE \\
\hline People communicating & $\begin{array}{l}\text { Importance of communication and dialogue } \\
\text { with real people }\end{array}$ & $\begin{array}{l}\text { I have learned how important } \\
\text { communication between human beings is. } \\
\text { Power of dialogue }\end{array}$ \\
\hline Similarities & $\begin{array}{l}\text { Focus on similarities, though differences } \\
\text { may be acknowledged }\end{array}$ & $\begin{array}{l}\text { We really all are the same, maybe different } \\
\text { beliefs and customs, but we do all want the } \\
\text { same things }\end{array}$ \\
\hline
\end{tabular}




\begin{tabular}{|c|c|c|}
\hline Difference & $\begin{array}{l}\text { Focus on accepting and respecting different } \\
\text { opinions and points of view (tolerance, } \\
\text { respect, dignity) }\end{array}$ & $\begin{array}{l}\text { I learned that having different backgrounds } \\
\text { is not a problem if you are predisposed to a } \\
\text { not-biased dialogue. }\end{array}$ \\
\hline Don't generalize & $\begin{array}{l}\text { The importance of not making } \\
\text { generalizations, awareness of having (had) } \\
\text { stereotypes. }\end{array}$ & $\begin{array}{l}\text { The most important thing I learnt was that } \\
\text { each one of us has his or her opinion about } \\
\text { Arabs, Muslims or Americans. We cannot } \\
\text { generalize: in other words, we cannot say } \\
\text { that all Arabs hate Americans for example. }\end{array}$ \\
\hline Open expression & $\begin{array}{l}\text { The ability and/or opportunity to express } \\
\text { one's opinions freely and openly }\end{array}$ & $\begin{array}{l}\text { I've never had the chance to express my } \\
\text { political points of view as free as I did in } \\
\text { Soliya } \\
\text { How to express your opinions - how to } \\
\text { respect others' opinions and cultures - how } \\
\text { to be substantive in discussing affairs } \\
\text { related to your religion or society }\end{array}$ \\
\hline Listen & Learning to listen to others' opinions & $\begin{array}{l}\text { To listen to others perspectives before } \\
\text { coming up with my own conclusions }\end{array}$ \\
\hline Media critical awareness & $\begin{array}{l}\text { Recognition of media role in } \\
\text { creating/reinforcing stereotypes }\end{array}$ & $\begin{array}{l}\text { I learned that you can not blindly trust the } \\
\text { media. Now I do my own research about } \\
\text { topics, looking at various viewpoints and } \\
\text { sources before forming an opinion. }\end{array}$ \\
\hline Reinforced stereotypes & Stereotypes seem to have been reinforced & $\begin{array}{l}\text { I've learned that people from the US are not } \\
\text { aware about what is going on in their } \\
\text { country and the world. }\end{array}$ \\
\hline
\end{tabular}

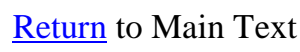

